\title{
A Magyar Biomechanikai TÁRSASÁG BEMUTATÁSA
}

\author{
Bojtár Imre \\ Budapesti Múszaki és Gazdaságtudományi Egyetem \\ ibojtar@mail.bme.hu
}

A Magyar Biomechanikai Társaságot az I. Magyar Biomechanikai Konferencián részt vevők alapították a budapesti és a debreceni Biomechanikai Kutatóközpontok előzetes javaslata alapján. A Konferencia a Budapesti Mû́szaki Egyetem Biomechanikai Kutatóintézetének szervezésében zajlott 2004 júniusában, magára az alakuló ülésre pedig a Konferencia utolsó napján, június 11-én került sor.

Mivel a BME Biomechanikai Kutatóintézet már a Konferencia szervezése során levélben elküldte a résztvevőknek a Társaság létrehozására vonatkozó indítványt, az alakuló értekezlet ennek a javaslatnak a megvitatásával kezdődött. 79-en vettek részt ezen az összejövetelen, többségükben mérnökök, orvosok, fizikusok, illetve biológusok. Az összegyúltek elôször egyhangú döntéssel kimondták a Társaság megalakulását, majd arról határoztak, hogy milyen formában múködjön a továbbiakban a Társaság. Hosszas vita után végül a jogi úton bejegyzendő társasági formát választották a jelenlevôk, feladatául tûzve ki a megválasztandó Vezetôségnek a szükséges szervezési teendők elintézését. Ennek a döntésnek megfelelően hagyták jóvá - a máig érvényes - múködési szabályzat szövegét is. Az Alapszabály a Társaság fó céljának a tudományos információcserét, a hazai kutatások összehangolását, valamint a hazai tudományos konferenciák megszervezését tekinti.

A Vezetôség tagjainak - ugyancsak egyhangú szavazással - a következô személyeket választották: elnök Stépán Gábor (Budapesti Múszaki Egyetem), elnökhelyettes Csernátony Zoltán (Debreceni Egyetem), vezetőségi ta- gok Kocsis László, Kurutzné Kovács Márta és Borbás Lajos, titkár Bojtár Imre (valamenynyien a Múegyetemrôl).

$\mathrm{Az}$ alapító értekezlet döntött a tagsági díj összegéről, végezetül pedig elfogadta Csernátony Zoltán javaslatát, hogy a II. Magyar Biomechanikai Konferenciát 2006 nyarán Debrecenben rendezzék meg.

Az alakuló ülést követôen a Vezetôség elindította a szükséges jogi lépéseket a Társaság hivatalos bejegyzése érdekében. 2004. október 6-án a Fôvárosi Bíróság „tudományos tevékenység, kutatás" múködési körrel jóváhagyta a nyilvántartásba vételt, ettől a dátumtól kezdve tehát „hivatalosan” is létezett az MBMT. Ezt követôen már az is lehetôvé vált, hogy a tagdíjak átutalásának fogadására önálló bankszámlát nyisson a Vezetôség.

Az alapítást követô években a Társaság alapvetốen azt a szerepet töltötte be tagjai életében, amire vállalkozott: folyamatosan értesítette a tagokat a biomechanikával kapcsolatos hazai és külföldi összejövetelekről, konferenciákról, pályázati lehetőségekről, tudományos hírekrôl. Nem hiányoztak a tagoknak elküldött - közel 100 darab - e-mailból a fiataloknak szóló állásajánlatok, a külföldi kapcsolatkeresési javaslatok, valamint a frissen megjelent könyvekről és egyéb kiadványokról szóló tájékoztatók sem.

A törvényi előírásoknak megfelelően 2005 májusában a Társaság megtartotta rendes évi közgyûlését. A Vezetőségből távozó Kocsis László helyére Halász Gábort (Mûegyetem) választották, jóváhagyták az új tagok felvételét 
Biomechanica Hungarica I. évfolyam, 1. szám

(a létszám az eredeti 79-rôl 85-re nôtt), és meghallgatták a debreceni Biomechanikai Konferencia szervezésével kapcsolatos kérdéseket.

2006 júliusában Debrecenben - a nagy sikerrel megrendezett II. Magyar Biomechanikai Konferencián - került sor a következő közgyúlésre. A létszám ekkorra már 90 fốre nốtt. Erre az időpontra készült el és vált rendszeres információs forrássá a Társaság honlapja is. A következő két évre Csernátony Zoltánt választották elnöknek, Stépán Gábort pedig alelnöknek. A Vezetôség tagja lett Noviczki Miklós, a Nyíregyházi Jósa András Kórház Traumatológiai Osztályának főorvosa is. A tagság egyhangúan úgy döntött, hogy ezentúl csak kétévenként, a Biomechanikai Konferenciák idôpontjában tart értékelő közgyúlést.

A 2007-es évet a további rendszeres tájékoztató munka jellemezte. Csernátony Zoltán

Bojtár Imre

Budapest Músszaki és Gazdaságtudományi Egyetem, Tartószerkezetek Mechanikája Tanszék 1111 Budapest, Múegyetem rkp. 3.

Tel.: (+36) $1463-1160$ javaslatára elkezdődött a Társaság lapjának, az nyomtatott kiadású, ISSN-számmal rendelkező „Biomechanica Hungarica” megjelentetésének előkészítése, és 2008. júniusi idôponttal meghirdetésre került a III. Magyar Biomechanikai Konferencia (az ismertetố írásának időpontjában is folynak a Konferencia előkészületei, eddig több mint 70 elôadó regisztráltatta magát). Amint látható a Konferenciára elkészült a Társaság lapjának elsố száma.

A Magyar Biomechanikai Társaság a megalakulása óta eltelt közel négy évben teljesítette fố célját: megismertette egymás tevékenységével a korábban sokszor elszigetelten dolgozó hazai kutatókat, segítette szinergikus jellegú új tudományos kapcsolatok létrehozását, és így egyre ismertebb és elismertebb hazai központjává vált a tagjai által múvelt kutatási területnek.
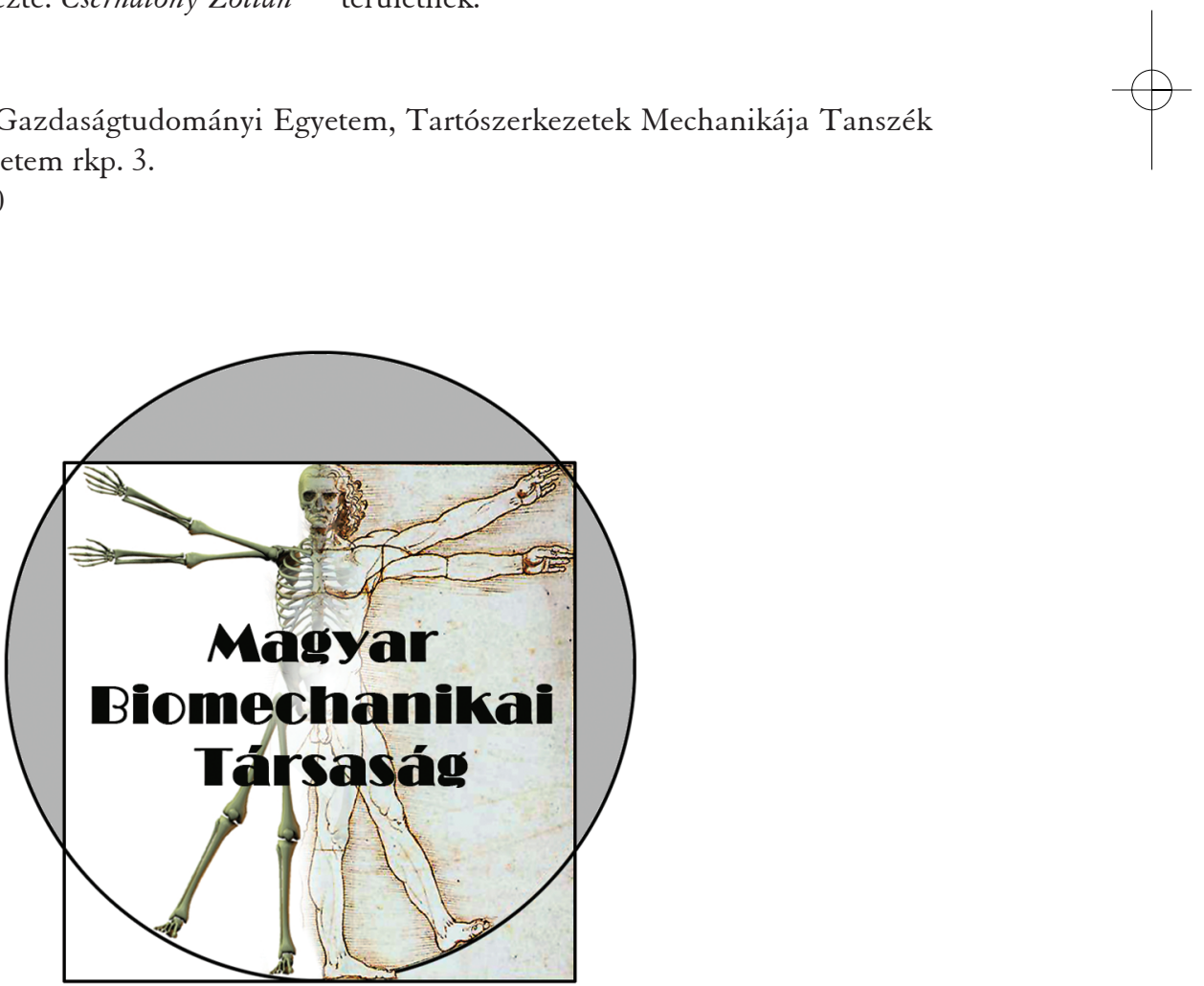

8 